Received 30.03.2017 Reviewed 05.05.2017 Accepted 13.06.2017

A - study design

B - data collection

C - statistical analysis

D - data interpretation

$\mathbf{E}$ - manuscript preparation

F - literature search

\section{Impact of urbanization}

on the sediment yield in tropical watershed using temporal land-use changes and a GIS-based model

\author{
Al-Amin D. BELLO ${ }^{\text {ABCDEF } ه}$, Noor B. HASHIM ${ }^{\text {ABCDEF }}$ \\ Ridza M. HANIFFAH ABCDEF
}

Universiti Teknologi Malaysia, Faculty of Civil Engineering, Department of Hydraulics and Hydrology, Skudai, 81300 Johor Bahru, Malaysia; e-mail: ask4alamin@gmail.com,drbaharim@yahoo.com,mridza@utm.my

For citation: Bello A.-A.D., Hashim N.B., Haniffah R.M. 2017. Impact of urbanization on the sediment yield in tropical watershed using temporal land-use changes and a GIS-based model. Journal of Water and Land Development. No. 34 p. 33-45. DOI: 10.1515/jwld-2017-0036.

\begin{abstract}
Abundant rainfall areas promote sediment yield at both sub-watershed and watershed scale due to soil erosion and increase siltation of river channel, but it can be curtailed through planned urbanization. The urbanization of Skudai watershed is analysed from historical and future perspective. A GIS-based model (Hydrological Simulation Programme-FORTRAN-HSPF) is used to modelled sediment flow using basin-wide simulation, and the output result is utilized in evaluating sediment yield reduction due to increased urbanization by swapping multiple temporal land-use of decadent time-steps. The analysis indicates that sediment yield reduces with increase urban built-up and decrease forest and agricultural land. An estimated 12400 tons of sediment will be reduced for every $27 \%$ increase in built-up areas under high rainfall condition and 1490 tons at low rainfall. The sensitivity analysis of land-use classes shows that built-up, forest and barren are more sensitive to sediment yield reduction compared to wetland and agricultural land at both high and low rainfall. The result of the study suggests that increased urbanization reduced sediment yield in proportion to the rainfall condition and can be used as an alternative approach for soil conservation at watershed scale independent of climate condition.
\end{abstract}

Key words: $H S P F$ model, land-use, rainfall, sediment yield, tropical watershed

\section{INTRODUCTION}

Rapid development due to increased human population and economic growth usually affect the physical geography of a watershed. It's altered the natural hydrology, increases streamflow [XIAN et al. 2007; ZHOU et al. 2013], and distortion of the river morphology [RUSSO et al. 2009; SELMI, KHANCHOUL 2016]. Because conversion of forest land to farmland and urban built-up often expose the soil to direct rainfall and runoff, therefore increase soil erosion. For instance, there has been an increased effort to understand the effects of environmental changes on sedi- ment yield [BORAH et al. 2001; DE VENTE et al. 2008; GUZMAN et al. 2017; KUMAR et al. 2014; PAK et al. 2015; ZEINIVAND, SMEDT 2009; ZHANG et al. 2013]. Some studies linked sediment yield with climate change [ZHANG et al. 2016], water quality [BAI, WU-SENG 2005; RUSSO et al. 2011], wildfire [CANFIELD et al. 2005], aquatic life [PAPANICOLAOU, ABACI 2005], soil condition [FOX, MARTIN 2014; ZHANG et al. 2016], and type of climate [MEKONNEN et al. 2016]. However, recent Studies have shown that a planned land-use can be an effective management tool for soil conservation and reduction of sediment at a watershed scale [XIAO et al. 2016; ZHAO et al. 2017]. 
In this study, we demonstrate the application of historical and future temporal land-use to evaluate the impact of planned urbanization to sediment yield reduction at sub-watershed and watershed scale. This approach integrates different temporal land-use into hydrological simulation program-Fortran (HSPF). The aimed is to evaluate the effectiveness of planned urbanization as an alternative soil conservation measures in a tropical watershed. As the climate are characterized by abundant rainfall that results in floods, soil and bank erosion, and siltation of river channel. Assessment of sediment yield is important in watersheds that discharge into the strait. Because it provide information on amount and rate of sediment depositions from watershed to estuary and guide development of natural resources [BORAH et al. 2008], though it is a complicated process [BARKDOLL, DUAN 2008].

The objective of the study is to determine the impact of planned urbanization on reduction of sediment yield using historical and future development land-use and GIS-based model (HSPF). Also to measure the sensitivity of land-use class to sediment yield as they varied over time and evaluate the significance of rainfall variability to sediment reduction with an increase urbanization.

\section{SKUDAI WATERSHED}

Skudai watershed is located in suburban Johor state of Malaysia, and the watershed has been developed for the past 30 years with projected $80 \%$ urbanization based on designed future development plan [IRDA 2011]. It falls between $102^{\circ} 59^{\prime} 54.19^{\prime}$ ' E and $104^{\circ} 11^{\prime} 8.54^{\prime}$ ' E longitude and $1^{\circ} 56^{\prime} 31.67^{\prime}$ ' $\mathrm{N}$ and $1^{\circ} 22^{\prime} 41.16$ ' $\mathrm{N}$ latitude, measures $33.54 \mathrm{~km}$ by 16.29 $\mathrm{km}$ width on both axes, with a total area of 287.44 $\mathrm{km}^{2}$. The entire length of the main river (Skudai River) was $42.8 \mathrm{~km}$. The watershed consists of four major tributaries; the Sengkang River, Senai River, Melana River and Danga River. Skudai watershed was among the 189 rivers system that flows into the sea in Malaysia [Government of Malaysia 2009]. Figure 1a-b shows an outlook of the Skudai watershed located in the southwest of Peninsular Malaysia. The major river (Fig. 1b) flows from the western part of Johor (Sedenak) to the southern part and discharges directly into Johor Strait. Skudai watershed falls in the region without a regular dry season, and with rainy seasons northeast monsoon (November to March) and southwest monsoon (June to September), with the transitional period between October to November and April to May. The general terrain of Skudai basin can be classified into four. The highest level of $100 \mathrm{~m}$ and above was located at the Northern end and the river catchments boundary. The steeper foothill of medium height ranging from $80 \mathrm{~m}$ to $100 \mathrm{~m}$ flanking the western and eastern side and terrain ranging from $60 \mathrm{~m}$ to $80 \mathrm{~m}$ occupies the middle region and at the river catchments boundaries. The broad belt of a flat area, below $40 \mathrm{~m}$ altitude fills in the central region. Examination of the river-course gradients shows the existence of steep sections at the upstream, and naturally graded stretches of low gradient and gentle flow at the downstream end towards the river mouth. Skudai watershed was considered as the most urbanized river system concerning population, development and settlement areas as compared to the other river system in Johor. The current river width varies along the reach, but the natural landscape was still maintained as natural since the river width increases downstream.
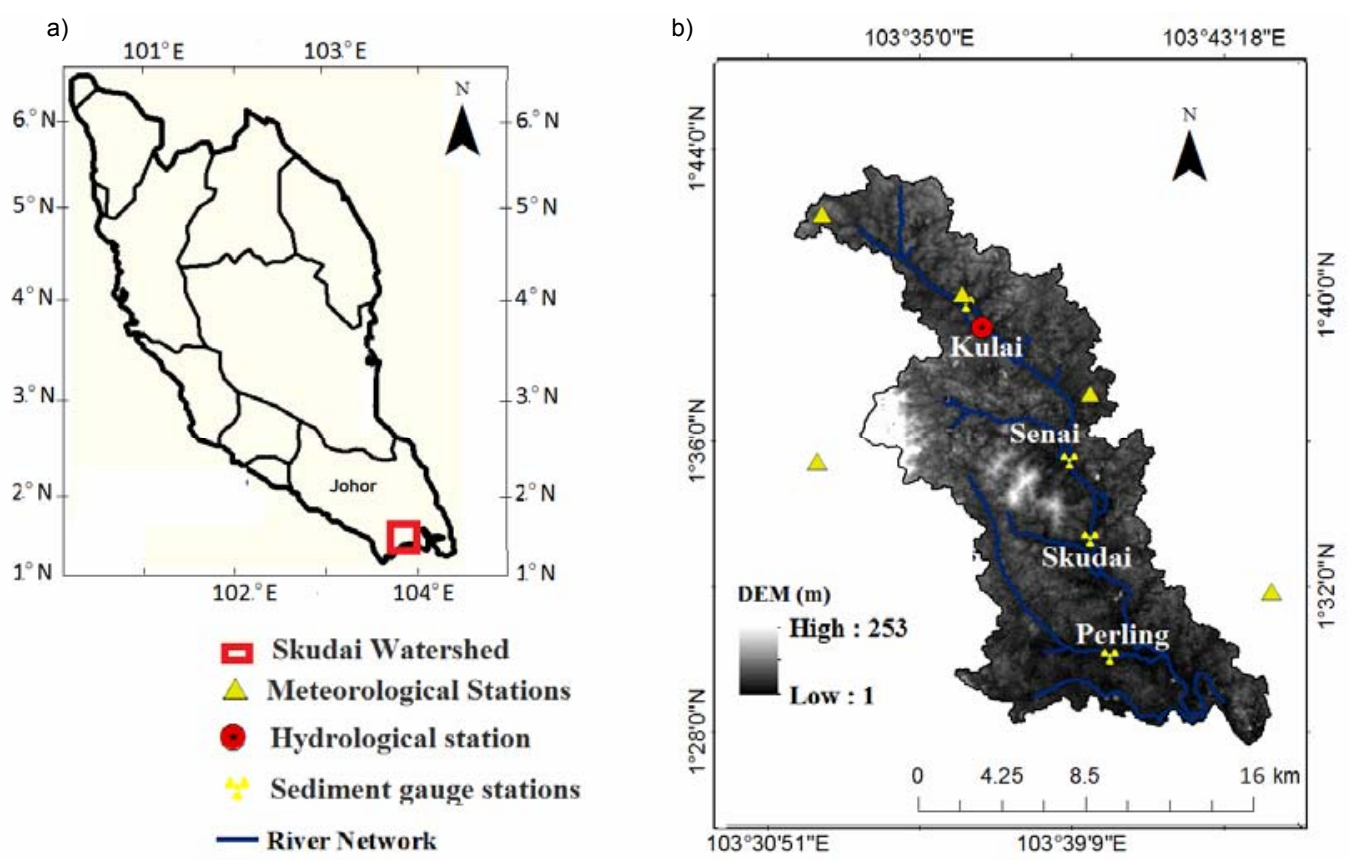

Fig. 1. Location of the Skudai watershed: a) map showing Skudai watershed in peninsular Malaysia, b) zoomed in map of Skudai with rivers network, distribution of rain gauges, hydrological and sediment (water quality) stations with topographical details; source: own elaboration 


\section{MATERIAL AND METHOD}

To achieve the objective of the study, an interdisciplinary approach was adopted in which remote sensing and land-change model (LCM) were used to gen- erate temporal land-use of decadal time-step. The produced land-use was integrated into a GIS-based model to evaluate the impact of urbanization on sediment yield at sub-watershed and watershed scale. The complete methodology was summarized in Figure 2.

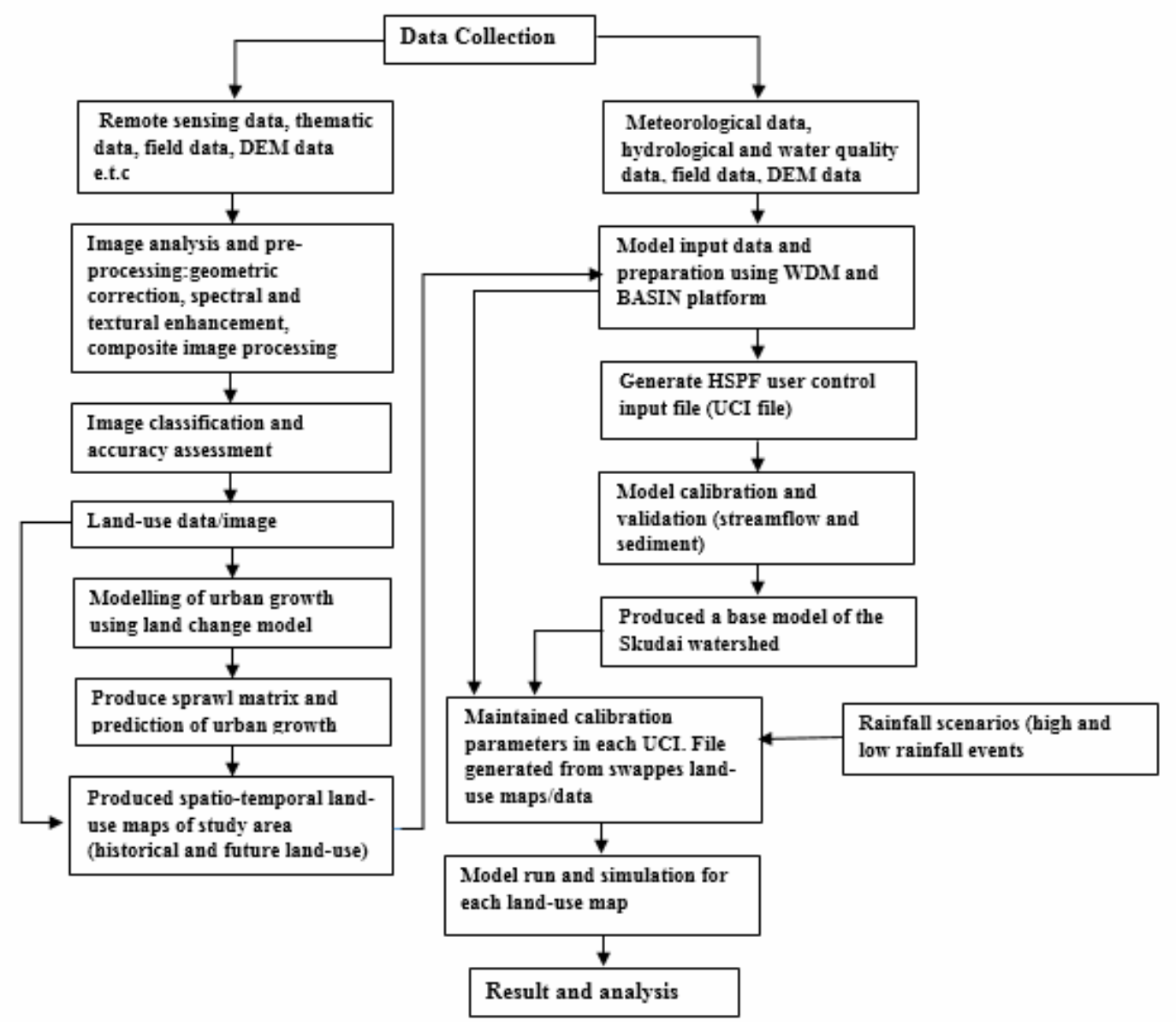

Fig. 2. Methodology flowchart; source: own elaboration

\section{MODELLING OF SEDIMENT IN HSPF}

Hydrological Simulation Program-Fortran (HSPF) was a semi-distributed model that was based on conceptual, lumped parameter modeling, which simulates streamflow, sediment, and chemical pollutants in both soil and instream [SHENK et al. 2012]. HSPF model produces time series result for streamflow, sediment flow, nutrient and pesticide loads at any location in the watershed. The model requires input data on land use, soil, point sources, drainage characteristics, and time series meteorological data. The model had three operation modules that handle all the modeling processes, pervious land (PERLND), impervious land (IMPLND) and reaches section (RCHRES). For sediment modeling, the model simulates three sediment types (sand, silt, and clay), by outsourcing them from the three modules. Basic equations for sediment modeling in HSPF model were documented by DONIGIAN and CRAWFORD [1976] and showed that in the previous segment, two component processes were in- volved. Detachment of silt and clay (fine soil) due to impact of rainfall, compute using Equation (1) and transport of the detached soil by surface runoff calculate by either Equation (2) or (3):

$$
\begin{gathered}
D(t)=(1-C(T)) \cdot K R E R \cdot P(t)^{J R E R} \\
S(t)=K S E R \cdot Q(t)^{J S E R} \text { if } S(t) \leq \widehat{S}(t) \\
S(t)=\widehat{S}(t) \text { if } S(t)>\widehat{S}(t)
\end{gathered}
$$

where: $D(t)=$ soil detachment at time $t\left(\mathrm{t} \cdot \mathrm{ha}^{-1}\right) ; C(T)=$ fraction of vegetative use intercepting rainfall as a function of duration of time within growing season (acre); KRER $=$ detachment coefficient; $P(t)=$ precipitation at time step $(\mathrm{mm}) ; J R E R=$ exponent for soil detachment); JSER = exponent for fine soil transport by surface runoff; $S(t)=$ fine soil transport by surface runoff $\left(\mathrm{t} \cdot \mathrm{ha}^{-1}\right) ; K S E R=$ transport coefficient; $\hat{S}(t)=$ fine soil storage at beginning of each time $t\left(\mathrm{t} \cdot \mathrm{ha}^{-1}\right)$; $Q(t)=$ surface runoff occurring at each time $t(\mathrm{cfs})$. 
At the impervious segment, the same approach in the pervious segment are maintained but using accumulation and removal of sediment from the impervious surfaces, as shown in Equation (4-7).

$$
\operatorname{SED}(T)=\operatorname{SED}(T-1) \cdot(1-R)+A C C
$$

At Equilibrium; $\quad S E D(T)=\frac{A C C}{R}$

$$
\begin{gathered}
T S S(t)=K E I M \cdot Q(t)^{J E I M} \text { if } T S S(t)<T S(t) \\
T S S(t)=T S(t) \text { if } T S S(t) \geq T S(t)
\end{gathered}
$$

where: $\operatorname{SED}(T)=$ sediment on the impervious land surface at duration $T ; S E D(T-1)=$ sediment on pervious land at duration $T-1 ; R=$ daily removal rate; $A C C$ $=$ daily accumulation rate of sediment; $\operatorname{TSS}(t)=$ sediment transport at time $t$; KEIM = coefficient of transport of impervious area; $Q(t)=$ surface runoff at time $t$; JEIM $=$ exponent of transport of impervious area; $T S(t)=$ deposition storage of impervious area.

In HSPF model, sediment from impervious and pervious areas were preceded to the stream at each time step after detachment and transport of sediment. Shear stress controls re-suspension and settling of cohesive solids (silt and clay) at the sediment-water interface. The channel geometry that carries the sand particles at a given flow is computed based on the settling and resuspension rate defined by the change in the sand in suspension and the channel capacity [MISHRA et al. 2007]. HSPF simulate the convection, scouring, and deposition in each reach on each constituent (silt, clay and sand). But in this study, silt and clay deposition were considered as wash-load that neither scoured nor deposited because of the soil texture of the study area. Maintaining the approach utilized by HAYASHI et al. [2004] of which volume of deposition of sand was computed as a function of the concentration of suspended sand while power function model was used to determine the volume of scouring of sand in each reach.

\section{DATASET}

Hourly precipitation records within the watershed were collected from Department of Irrigation and Drainage of Malaysia (DID), for the duration of 29 years (1986-2015). Other meteorological data (dew temperature, cloud use, solar radiation, evaporation and wind speed, and direction) were obtained from Malaysia Meteorological Department (MMD) and National Oceanic and Atmospheric Administration (NOAA) under National Centre for Environmental Information (access on the platform of climate data online). These data were used to build input database for model run via watershed data management file (WDM). Monthly streamflow data were collected from DID and in-stream monthly sediment flows data from the Department of Environment of Malaysia (DOE).This data were used for calibration and validation of HSPF model. The topographic data of the wa- tershed was obtained from Global data Explorer (Fig. 1b) with $30 \mathrm{~m}$ resolution and $7.5 \mathrm{~min}$, one arc sec interval digital elevation model (DEM) and was used for model setup. Local soil data was collected from the soil survey division of Ministry of Agriculture and Fisheries, Malaysia. The soil classes and their boundaries within the study area were generated using ArcGIS. Textural grouping was used to classify the soil in the catchment as depicted in Figure 3. The dominant soil texture was sand $(78.0-81.2 \%)$, follow by clay $(16.7-20.0 \%)$ and silt $(2.0-2.1 \%)$.

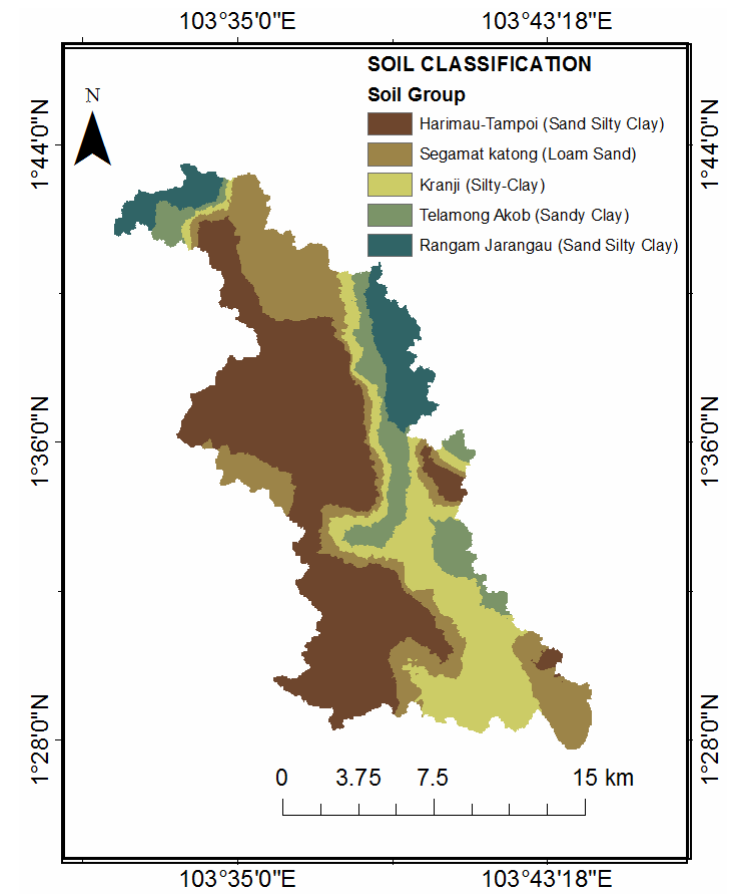

Fig. 3. Soil textural classification map of Skudai Watershed; source: own elaboration

The land use data of Skudai watershed for the last three decades were derived from remote sensing data. The remote sensed imagery were obtained from USGS EROS data centre (EDC), through USGS Global Visualization Viewer (GLOVIS). The imageries were captured using Landsat 4-5, Landsat 7 of thematic mapper (TM) and enhanced thematic mapping $(\mathrm{ETM}+)$ at spatial resolutions of $30 \times 30 \mathrm{~m}$. The data characteristics were shown in Table 1.

\section{LAND USE CLASSIFICATION AND PREDICTION}

The remote sensing data were used to produce land-use for each corresponding year of the imagery. Although the images have varied quality and product, it was ensured that they have the same pixel level and enhanced spatial resolution, textural, and structural details. ArcGIS (v. 10.3) software, was used for geometric correction, land use classification [SUDHIRA et al. 2004] and accuracy assessment [FOODY 2002]. The historical and current base maps of the study area couple with field data were used for identification of targeted five land-use classes. 
Table 1. Input data summary

\begin{tabular}{|l|l|c|c|c|l|}
\hline Data type & \multicolumn{1}{|c|}{ Data name } & Period cover & $\begin{array}{c}\text { Time step/ } \\
\text { resolution }\end{array}$ & $\begin{array}{c}\text { Sampling } \\
\text { method }\end{array}$ & Sources \\
\hline Climate data & $\begin{array}{l}\text { rainfall, temperature, wind } \\
\text { speed, cloud cover, solar } \\
\text { radiation and evaporation }\end{array}$ & $1999-2015$ & hourly & - & $\begin{array}{l}\text { Department of Irrigation and Drainage (DID), } \\
\text { Malaysia Meteorological Department (MMD) } \\
\text { and NOAA climate data online }\end{array}$ \\
\hline Hydrological & hydrological & $2002-2014$ & monthly & in-situ & Department of Irrigation and Drainage \\
\hline Water quality & sediment data & $2002-2014$ & monthly & in-situ & Department of Environment, Malaysia \\
\hline Spatial & DEM & 2010 & $30 \times 30 \mathrm{~m}$ & - & USGS global data explorer \\
\hline Spatial & land use & $1989-2039$ & $30 \times 30 \mathrm{~m}$ & - & generated using remote sensing \\
\hline Spatial & soil & 1970 & $1: 250,000$ & - & Ministry of Agriculture Malaysia \\
\hline Landsat & remote sensing imagery & $1989-2015$ & $30 \times 30 \mathrm{~m}$ & - & USGS global visualization data online \\
\hline
\end{tabular}

Source: own elaboration.

The supervised classification method was used to classify the watershed landscape for each land-use class separately. This process ensured optimal accommodate of the position of a pixel linked to the boundary line between two or more pre-defined classes [SUN et al. 2007]. The method searches for the pixel with most likely variance within the inter-class and less possible variance within the intra-class [WEBER, PUISSANT 2003]. These produce a multi-class image of different pixels level. The land-use classification accuracy were measured using confusion matrix and kappa index as a base quantitative metrics of classification accuracy. The changes in land-use were determined from the multi-date post-classification comparison as a direct approach to change detection [JENSEN 2004].

The historical and planned future development of the watershed was used as a constraint to predict future land-use from the historical land use data generated, applying Land Change Model (LCM). The model assumes that the characteristics growth calibrated between the two land-use of different time step will stay identical for any other periods considered in the future. In this study, 1989 and 2009 land-use were used to calibrate the real expansion in built-up area and future planned development by IRDA [2011] was utilized as a constraint. The generated sprawl matrix was applied to predict 2015 land-use and validated with the actual land-use (produce by remote sensing) of the same year. After validation of the LCM model, it was then used to predict land-use for the year 2019, 2029, and 2039.

\section{HSPF MODEL SETUP AND EVALUATION}

The processed climatic database in WDM file format, topography, land-use, and soil properties are integrated in the BASINS interface. The 2013 landuse was utilized as the base land-use and BASINS' automatic delineation tool was used to delineate and subdivide the watershed into thirty (30) hydrologic response units $(H R U s)$. It was also used to process, land use characteristics and topographical details such as; reaches and stream slopes, stream lengths, widths, and depths were transferred to HSPF's User Control Input file. The initial (not calibrated) HSPF model was generated from BASINS interface. Observed monthly streamflow data from the upstream of the watershed at Kulai were used for the streamflow calibration. Six years of streamflow data (2002-2007) were used for model calibration, and another six years of flow data (2009-2014) for model validation. For sediment, seven years data (2002-2008) were used for model calibration, and an additional six years data (2009-2014) were used for model validation at four water quality gauged stations at Kulai, Senai, Skudai and Perling. Because of data limitation, the streamflow was calibrated and validated only at kulai station while sediment was calibrated and validated at four stations.

Having calibrate and validate the model using observed data, the visualization of the model calibration results were produced directly from the HSPEXP+ program package [Aqua Terra 2016]. It generates the output of the simulated and observed data from the graph specification file. The HSPF model performance is evaluated using coefficient of determination $\left(R^{2}\right)$, the Nash-Sutcliffe coefficient (NS), percentage bias (PBIAS/mean percent error) and RSR error index and the equation are shown below.

$$
\begin{gathered}
R^{2}=\left(\frac{\sum\left(Q_{o}-\hat{Q}_{o}\right)\left(Q_{s}-\hat{Q}_{s}\right)}{\sqrt{\sum\left(Q_{o}-\hat{Q}_{o}\right)^{2}} \sqrt{\sum\left(Q_{s}-\hat{Q}_{s}\right)^{2}}}\right)^{2} \\
N S=1-\frac{\sum\left(Q_{s}-Q_{o}\right)^{2}}{\sum\left(Q_{o}-\hat{Q}_{o}\right)^{2}} \\
P B I A S=\frac{\sum\left(Q_{o}-Q_{s}\right)}{\sum Q_{o}} 100 \\
R S R=\frac{R M S E}{S D_{o}}=\frac{\sqrt{\sum\left(Q_{o}-Q_{s}\right)^{2}}}{\sqrt{\sum\left(Q_{o}-\hat{Q}_{o}\right)^{2}}}
\end{gathered}
$$

where: $Q_{o}$ and $Q_{s}=$ the observed and simulated data, $\hat{Q}_{o}$ and $\hat{Q}_{s}=$ the mean observed and simulated data, $N=$ the total number of data.

\section{IMPACT OF URBANIZATION ON SEDIMENT REDUCTION}

After calibration of the model using 2013 landuse as the base model, other land-use (both historical and projected) for the year 1989, 1999, 2009, 2019, 2029 and 2039 were swapped to generate separate HSPF model input file. The base calibration parameters were maintained for each land-use swapped and 
the model was run. Final output result for each simulation were used to compute sediment yield contribution at each sub-watershed and at the watershed outlet. Analysis of the sediment yield at sub-watershed scale was performed using spatial analysis.

The sensitivity (absolute relative sensitivity) of sediment yield to urbanization increase (change in land-use) were determined using the relationship illustrated below.

$$
Y_{i}=\frac{\left|X_{i}-X_{a}\right|}{X_{a}}
$$

where $Y=$ a sensitivity coefficient (relative change of sediment yield contributed by land use class on the watershed sediment yield) for chosen land use year, $X=$ sediment yield contributed by land use class in a given year, $i=$ swapped land use of a given year used to generate sediment yield, $a=$ the earliest land use generated sediment yield.

The aimed of the sensitivity analysis was to allow us to identify the magnitude of a single land-use composition (forest land, agriculture, built-up, wetland or barren land) to influence sediment yield and to quantitatively understand their impacts at watershed scale.

\section{SEDIMENT YIELD WITH RAINFALL VARIABILITY}

Rainfall events profoundly modify the sediment yield in both lands and instream. The effect of rain to sediment yield with increased urbanization were further studied, employing two scenarios; high rainfall ( $40 \%$ increase) and low rainfall (30\% decrease) scenarios. The high and low rainfall events were computed by determining the difference between the high and low precipitation years and the annual average over the whole period in view. This means, in the wet years, it will be $40 \%$ more rain than the yearly average in Skudai watershed, wherein dry years, 30\% less rain were considered. The amount of sediment yield from the two rainfall scenarios using the six land-use maps were evaluated. This was to observe whether impact of land-use on reduction of sediment yield can be impacted by rainfall conditions.

\section{RESULTS AND DISCUSSION}

\section{URBANIZATION IN SKUDAI WATERSHED}

The land-use of the Skudai watershed for the years 1989, 1999, 2009, 2013 and 2015 were produced using remote sensing data, with $30 \times 30 \mathrm{~m}$ resolution each. Five land-use classes were developed (urban built-up, agriculture, forest, water/wetland and bare land) based on the natural landscape of the watershed. The change in the distribution of land-use between 1989 and 2009 was used to project future land-use with the assumption of constant urbanization rate and maintaining planned future development in the watershed. For year 1989, the distribution of landuse classes (Fig. 4a) in the watershed was 50.3\% forest, $25.3 \%$ agricultural land, $18.2 \%$ urban, $4.6 \%$ wetlands and $1.2 \%$ barren land. Twenty (20) years after, in 2009 (Fig. 4c) the distribution of land-use changes to $34.8 \%$ forest, $27.4 \%$ agriculture, $36 \%$ urban, $1.4 \%$ wetland and $0.4 \%$ barren land, an indication of rapid urbanization. The predicted land-use shows (Fig. $4 \mathrm{~d}-\mathrm{f}$ ) a continues distribution of the land-use classes, for example, 2039 predicted land-use shows $22.1 \%$ forest, $27.3 \%$ agriculture, $49.2 \%$ urban, $0.8 \%$ wetland and $0.58 \%$ barren land. A sign of consistent increased in urbanization. The relative changes in built-up land from 1989 to 2013 shows an increase of $102.36 \%$ and from 1989 to 2039 was expected to increase by $169.9 \%$. But forest land shows a decrease of $56 \%$ from 1989 to 2039 and $37.48 \%$ from 1989 to 2013 while agricultural land will increase to $6.3 \%$ by 2039 as summarized in Table 2.

\section{HSPF MODEL CALIBRATION AND VALIDATION}

The model was calibrated and validated using monthly data for streamflow in the periods of 20022007 and 2009-2014 at Kulai gauge station. While sediment was calibrated with the monthly observed values for instream suspended solid (SS) concentration using data collected from 2002-2008 and validated with the data collected between 2009-2014 at four stations (Kulai, Senai, Skudai, and Perling). The detachment of soil by rainfall was simulated for all the land use classes, but with a different percentage of soil exposure to rainfall drop (Tab. 3). Forest land and urban built-up were calibrated at $10 \%$ soil exposure but agricultural and wetland at $35 \%$ and $90 \%$ exposure to the rain drop. The sensitivity analysis of the sediment calibration parameter shows that the coefficient KRER and exponent JRER were the most sensitive parameters, while JSER, JGER, and COVER shows a different sensitivity index. The calibrated parameters in Table 3, indicates that the values of the coefficient and exponents in the model equation falls within the range suggested in BASINS Technical Note 8 [USEPA 2006]. The visual model calibration and validation results for both streamflow and sediment were shown in Figures 5 and 6. Table 4 shows the model performance statistics between the monthly observed and simulated streamflow at Kulai and sediment (at the four stations). However, the observed sediment data used for the calibration were collected during dry condition (no-rainfall) and the data do not captured storm events (high rainfall) in the watershed. Therefore, observed data were used as the baseline for the calibration and validation of the model targeting low flow events. The model performance for the streamflow was good while that of sediment (TSS at four stations) shows a good calibration and validation at Senai, Kulai, and Skudai with Perling station having the lowest calibration and validation performance indices [MORIASI et al. 2007]. In general, the graphical 


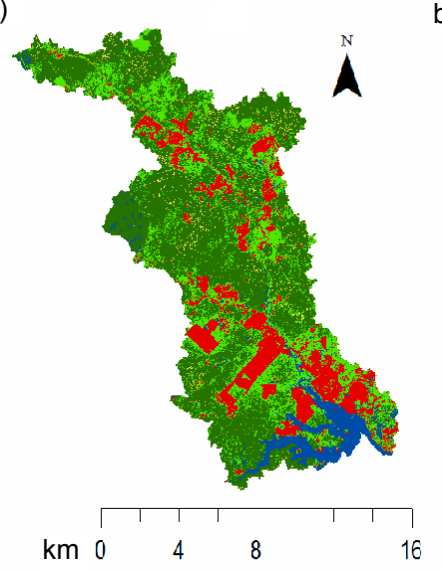

d)

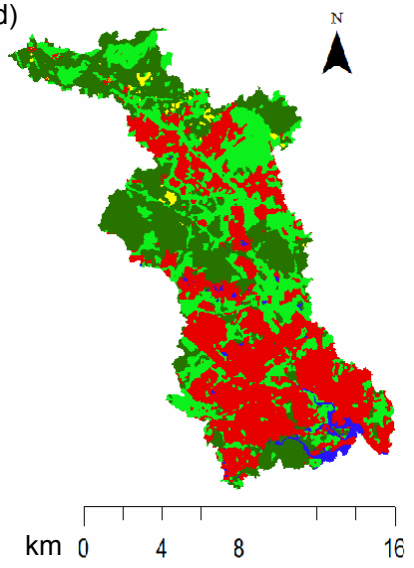

b)

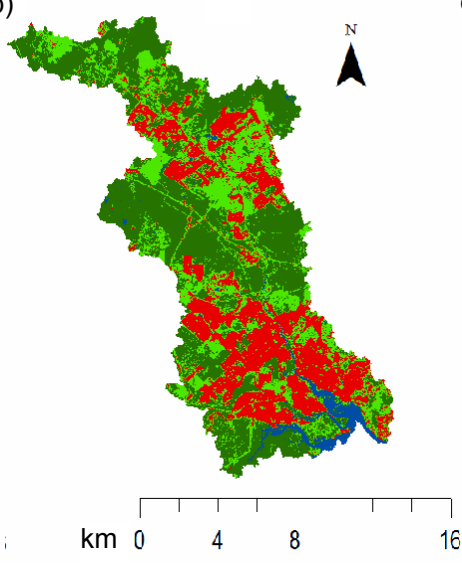

c)

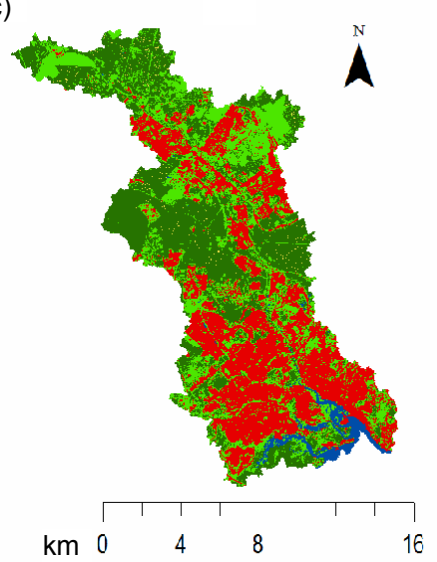

e)

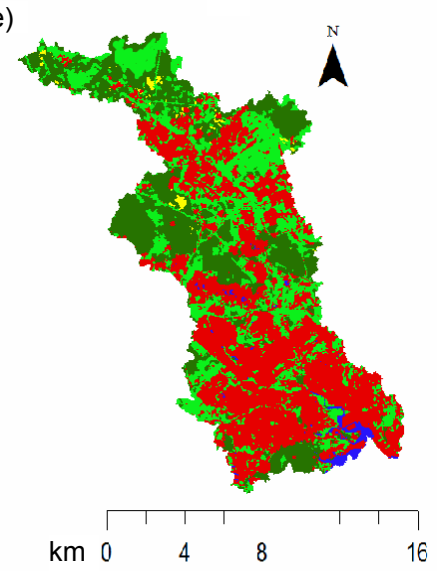

f)



\section{Built-up land Water/Wetland Agricultural land $\quad$ Barren land \\ Forest land}

Fig. 4. Temporal land-use of Skudai Watershed: a) 1989, b) 1999, c) 2009, d) 2019, e) 2029, f) 2039; source: own elaboration

Table 2. Land use characteristics over time and change detection

\begin{tabular}{|c|c|c|c|c|c|c|c|c|c|c|}
\hline \multirow{2}{*}{ Land use class } & \multicolumn{3}{|c|}{ Historical land use, $\%$} & \multirow{2}{*}{$\frac{\text { Base land use, } \%}{2013}$} & \multicolumn{3}{|c|}{ Predicted land use, $\%$} & \multicolumn{3}{|c|}{ Relative change, $\%$} \\
\hline & 1989 & 1999 & 2009 & & 2019 & 2029 & 2039 & 1989-2039 & $1989-2013$ & $2013-2039$ \\
\hline Built-up land & 18.24 & 30.54 & 36.00 & 36.91 & 40.22 & 45.79 & 49.23 & 169.90 & 102.36 & 33.38 \\
\hline Agriculture & 25.66 & 28.22 & 27.44 & 29.29 & 29.45 & 28.28 & 27.27 & 6.27 & 14.15 & -6.90 \\
\hline Forest land & 50.30 & 39.15 & 34.75 & 31.45 & 28.46 & 24.36 & 22.11 & -56.04 & -37.48 & -29.70 \\
\hline Water/wetland & 4.61 & 2.07 & 1.44 & 1.54 & 1.03 & 0.92 & 0.81 & -82.43 & -66.59 & -47.40 \\
\hline Barren land & 1.19 & 0.02 & 0.36 & 0.81 & 0.84 & 0.65 & 0.58 & -51.26 & -31.93 & -28.40 \\
\hline
\end{tabular}

Source: own study.

Table 3. Calibrated values of sediment control parameters

\begin{tabular}{|l|l|c|c|c|c|c|}
\hline Parameter & \multicolumn{1}{|c|}{ Definition } & Agriculture & Built-up & Barren & Forest & Wetland \\
\hline SMPF & supporting management practice factor & 0.20 & 0.20 & 0.20 & 0.20 & 0.20 \\
\hline KRER & coefficient in the soil detachment equation & 0.65 & 0.32 & 0.29 & 0.52 & 0.003 \\
\hline JRER & exponent in the soil detachment equation & 2.50 & 2.00 & 2.50 & 2.50 & 2.50 \\
\hline AFFIX & fraction by which detached sediment storage decreases & 0.01 & 0.04 & 0 & 0.002 & 0.00 \\
\hline COVER & fraction land surface protected from rainfall & 0.65 & 0.90 & 0 & 0.90 & 0.10 \\
\hline NVSI & atmospheric addition to sediment storage & 2.00 & 2.00 & 2.00 & 2.00 & 2.00 \\
\hline KSER & coefficient in the detached sediment wash off equation & 0.21 & 0.19 & 0.21 & 0.20 & 0.10 \\
\hline JSER & exponent in the detached sediment wash off equation & 2.00 & 2.00 & 2.00 & 2.00 & 2.00 \\
\hline KGER & coefficient in soil matrix scour equation & 0.96 & 0.80 & 1.30 & 0.92 & 0.08 \\
\hline JGER & exponent in soil matrix scour equation & 1.00 & 1.00 & 1.00 & 1.00 & 1.00 \\
\hline
\end{tabular}

Source: own study. 


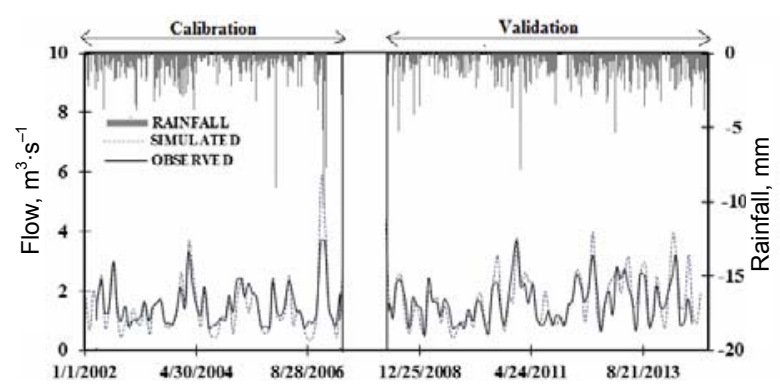

Fig. 5. Measured and simulated streamflow for calibration and validation period at monthly time step; source: own study
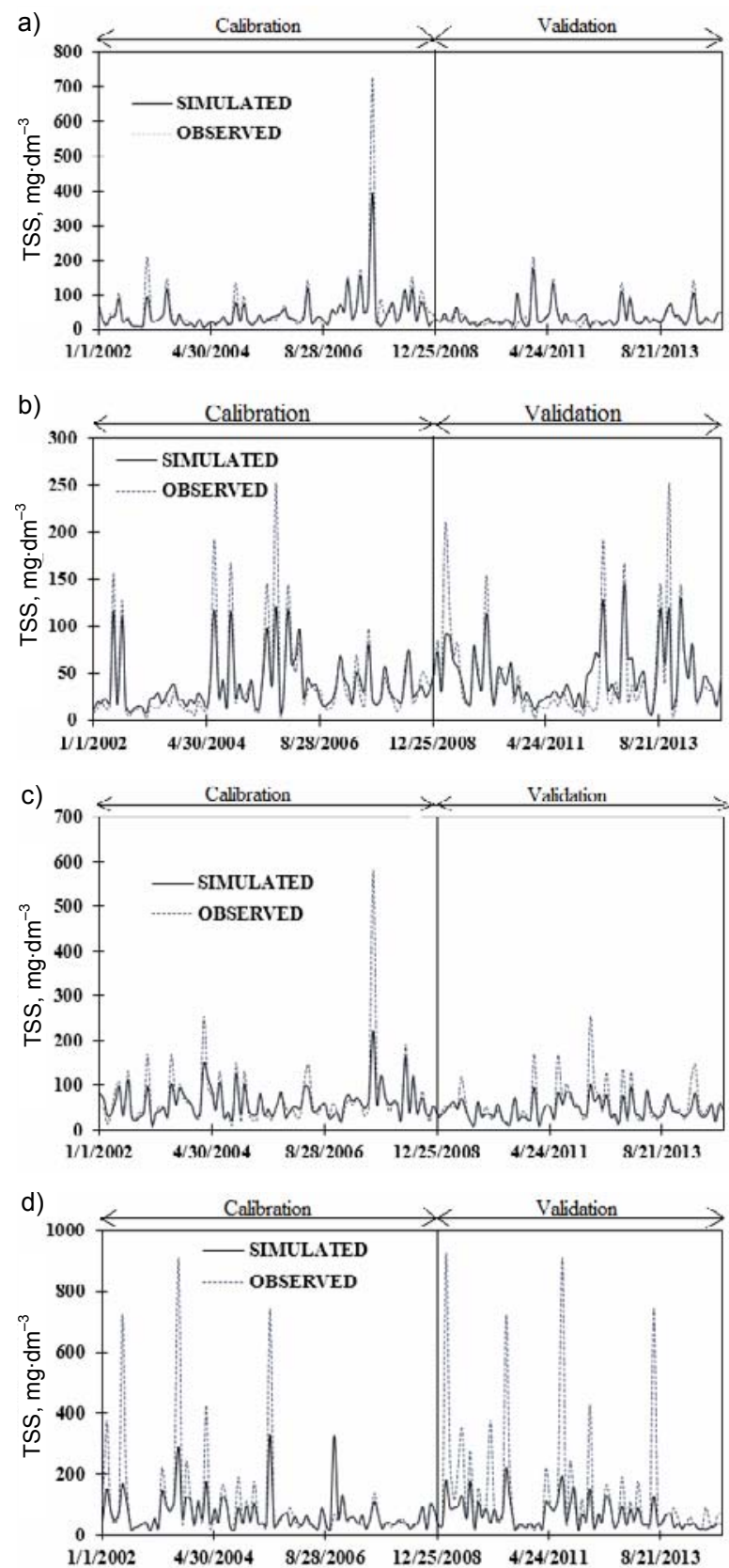

Fig. 6. Observed and simulated total suspended solids (TSS) concentration at: a) Kulai station, b) Senai station, c) Skudai station, d) Perling station; calibration and validation; source: own study agreement between observed and simulated result shows good calibration and validation over the range of the observed streamflow and SS concentration.

\section{INFLUENCE OF URBANIZATION ON SEDIMENT YIELD}

The annual sediment yield for each sub-watershed was computed under different land-use to analyse the impact of urbanization on sediment reduction of Skudai watershed. Figure 7 shows the spatial distribution of sediment yield in each sub-watershed based on temporal land-use changes. The sediment distribution maps show that as urbanization increased, sediment yield at sub-watershed scale decreases. Sub-watersheds that were dominated by forest land shows the same characteristics with sub-watersheds that were dominated by built-up areas, because the content of the forest (especially the green zone and reserved forest) was consolidated in sequence with the built-up lands. Also, sub-watershed with the least sediment yield were dominated by urban areas in most of the land-use dataset and account for the percent of builtup land for each land-use considered as shown in Table 5. It also shows that the steepness of the bed slope also contribute to the amount sediment yield in a watershed. BERGHOUT and MEDDI [2016] shows similar result in their study on sediment transport under flood events. However in our case, we observed that subwatershed with higher sediment yield were mostly forest and agricultural dominated areas which correspond to the study conducted by XIAO et al. [2016]. It further shows that as the urbanization increase the average slope of the sub-watersheds with higher sediment yield decreases due to the continues consolidation of agricultural and forest land in open areas and conversion of rough areas to urban built-up (although some conserved forest lands were in the high topographic areas). It was also observed that the amount of sediment yield contributed by each temporal land-use class varied as urbanization increase. Built-up land contribution to sediment yield increases while forest, agriculture, wetland and barren land contribution decreases.

Figure 8 shows the sensitivity of the land-use classes to sediment contribution as they varied over time. It indicates that built-up areas were more sensitivity to sediment yield, follows by barren land, then forest land. Agricultural land and wetlands show less sensitivity to sediment yield. With further increase in urbanization, the sensitive nature of urban built-up to sediment yield will continue to change while the sensitivity for the forest, agricultural, barren and wetland will remain unchanged because agricultural lands were expected to remain constant while some percent of wetland and forest land will continue to be as conservation areas. At sub-catchment level, agricultural land was mostly lower than forest land as shown in Table 5, and the dominant land-use class influences the net effect of sediment contribution with little in- 
Table 4. Model performance for simulation of streamflow and sediment yield

\begin{tabular}{|c|c|c|c|c|c|c|c|c|c|}
\hline \multirow{3}{*}{$\begin{array}{l}\text { Modelling } \\
\text { category }\end{array}$} & \multirow{3}{*}{ Location } & \multicolumn{8}{|c|}{ Model performance result } \\
\hline & & \multicolumn{2}{|c|}{$R^{2}$} & \multicolumn{2}{|c|}{$N S E$} & \multicolumn{2}{|c|}{ PBIAS } & \multicolumn{2}{|c|}{$R S R$} \\
\hline & & calibration & validation & calibration & validation & calibration & validation & calibration & validation \\
\hline Streamflow & Kulai & 0.89 & 0.83 & 0.88 & 0.82 & -6.28 & -3.91 & 0.34 & 0.42 \\
\hline \multirow{4}{*}{$\begin{array}{l}\text { Sediment } \\
\text { flow }\end{array}$} & Kulai & 0.91 & 0.78 & 0.78 & 0.71 & 16.80 & -6.62 & 0.47 & 0.42 \\
\hline & Senai & 0.88 & 0.79 & 0.81 & 0.76 & 5.26 & 1.01 & 0.43 & 0.49 \\
\hline & Skudai & 0.79 & 0.76 & 0.68 & 0.64 & 10.03 & 15.85 & 0.56 & 0.60 \\
\hline & Perling & 0.73 & 0.69 & 0.68 & 0.53 & 17.81 & 29.22 & 0.52 & 0.61 \\
\hline
\end{tabular}

Explanations: $R^{2}=$ coefficient of the determination, $N S E=$ Nash-Sutcliffe efficiency, PBIAS = percent bias, $R S R=$ ratio of root mean square error and standard deviation

Source: own study.

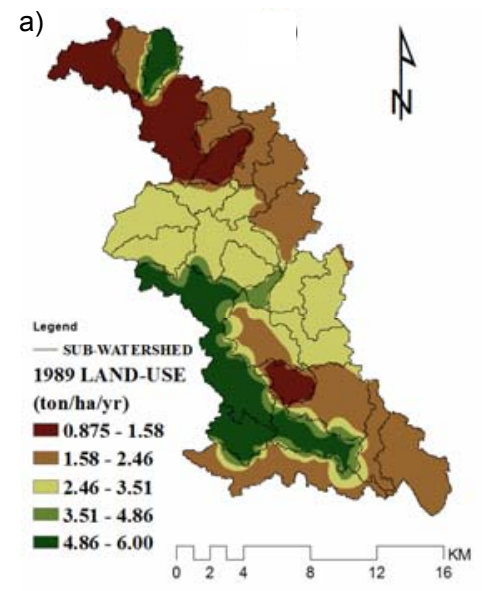

d)

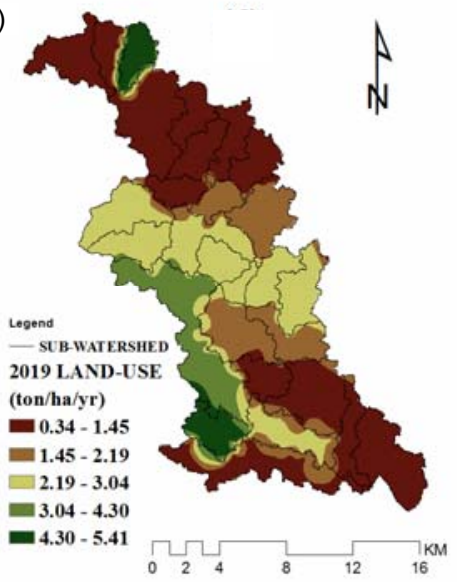

b)

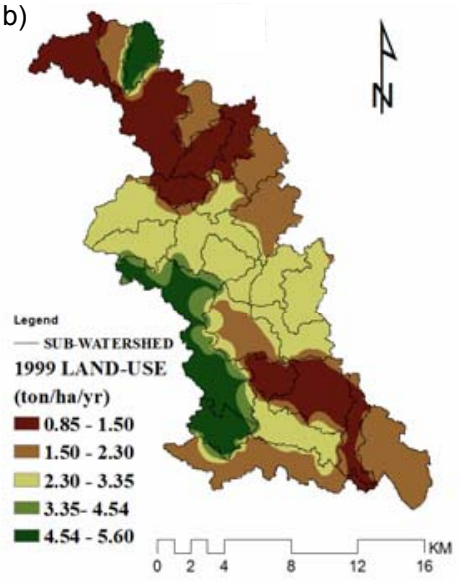

e)

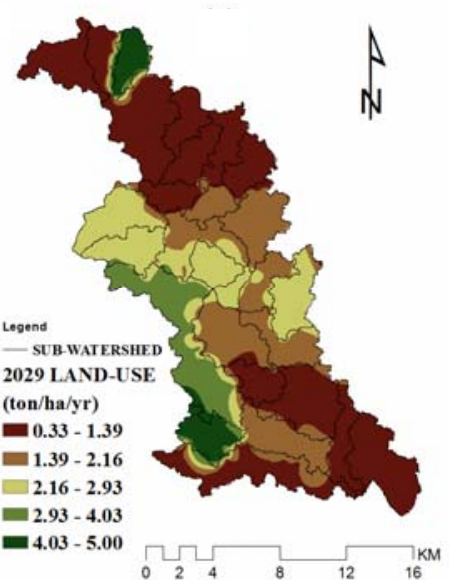

c)


Fig. 7. Distribution of sediment yield $\left(\mathrm{t} \cdot \mathrm{ha}^{-1} \cdot \mathrm{yr}^{-1}\right)$ at sub-watershed scale: a) 1989 land-use, b) 1999 land-use, c) 2009 land-use, d) 2019 land-use, e) 2029 land-use, f) 2039 land-use; source: own study

Table 5. Temporal land-use composition and average slope for each ranged of Sediment yield at sub-watershed scale

\begin{tabular}{|c|c|c|c|c|c|c|c|c|}
\hline \multirow{2}{*}{$\begin{array}{c}\text { Time-scale } \\
\text { years }\end{array}$} & \multirow{2}{*}{ 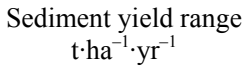 } & \multirow{2}{*}{$\begin{array}{l}\text { Watershed } \\
\text { area cover, \% }\end{array}$} & \multicolumn{5}{|c|}{ Land-use, \% } & \multirow{2}{*}{$\begin{array}{l}\text { Average } \\
\text { slope, \% }\end{array}$} \\
\hline & & & built-up & agriculture & forest & wetlands & barren & \\
\hline 1 & 2 & 3 & 4 & 5 & 6 & 7 & 8 & 9 \\
\hline \multirow{5}{*}{1989} & $0.87-1.58$ & 18.15 & 13.42 & 25.50 & 55.10 & 3.16 & 2.83 & 14.36 \\
\hline & $1.58-2.46$ & 41.34 & 18.33 & 25.43 & 46.41 & 8.23 & 1.60 & 13.50 \\
\hline & $2.46-3.51$ & 24.71 & 19.65 & 27.32 & 46.76 & 3.84 & 2.44 & 16.89 \\
\hline & $3.51-4.86$ & 7.95 & 24.92 & 24.28 & 40.44 & 5.81 & 4.56 & 13.86 \\
\hline & $4.86-6.00$ & 7.94 & 19.94 & 17.12 & 52.04 & 4.32 & 6.58 & 13.99 \\
\hline \multirow{5}{*}{1999} & $0.85-1.50$ & 31.95 & 27.71 & 29.55 & 39.00 & 2.75 & 0.99 & 13.67 \\
\hline & $1.53-2.30$ & 31.43 & 31.44 & 22.52 & 40.93 & 4.10 & 1.01 & 13.49 \\
\hline & $2.30-3.35$ & 27.17 & 36.47 & 30.01 & 29.96 & 2.40 & 1.17 & 16.61 \\
\hline & $3.35-4.54$ & 3.75 & 13.48 & 29.64 & 40.27 & 8.32 & 8.30 & 13.49 \\
\hline & $4.54-5.60$ & 5.79 & 11.81 & 29.73 & 47.64 & 5.45 & 5.38 & 13.53 \\
\hline
\end{tabular}


cont. Tab. 5

\begin{tabular}{|c|c|c|c|c|c|c|c|c|}
\hline 1 & 2 & 3 & 4 & 5 & 6 & 7 & 8 & 9 \\
\hline \multirow{5}{*}{2009} & $0.43-1.26$ & 33.65 & 34.88 & 29.34 & 32.09 & 2.17 & 1.52 & 13.96 \\
\cline { 2 - 9 } & $1.26-2.03$ & 32.38 & 38.88 & 27.27 & 29.39 & 3.35 & 1.11 & 13.95 \\
\cline { 2 - 9 } & $2.03-3.24$ & 24.45 & 36.72 & 26.70 & 33.44 & 1.78 & 1.36 & 17.06 \\
\cline { 2 - 9 } & $3.24-4.61$ & 3.95 & 17.77 & 22.23 & 43.68 & 7.86 & 8.45 & 14.91 \\
\cline { 2 - 9 } & $4.61-5.46$ & 5.67 & 11.42 & 16.38 & 60.04 & 5.55 & 6.60 & 13.84 \\
\cline { 2 - 9 } & $0.34-1.45$ & 32.44 & 39.08 & 31.00 & 26.82 & 1.57 & 1.54 & 13.76 \\
\cline { 2 - 9 } & $1.45-2.19$ & 30.54 & 38.67 & 23.38 & 33.49 & 2.48 & 1.98 & 13.95 \\
\cline { 2 - 9 } & $2.19-3.04$ & 27.57 & 46.50 & 32.36 & 17.37 & 2.26 & 1.51 & 17.75 \\
\cline { 2 - 9 } & $3.04-4.30$ & 3.92 & 18.36 & 27.89 & 37.41 & 7.93 & 8.41 & 13.49 \\
\hline \multirow{5}{*}{2029} & $4.30-5.41$ & 5.63 & 12.00 & 25.02 & 48.81 & 5.51 & 8.65 & 11.73 \\
\cline { 2 - 9 } & $0.33-1.39$ & 42.58 & 42.27 & 28.75 & 26.65 & 1.19 & 1.14 & 13.54 \\
\cline { 2 - 9 } & $1.39-2.16$ & 22.20 & 47.78 & 22.19 & 24.88 & 2.88 & 2.27 & 13.49 \\
\cline { 2 - 9 } & $2.16-2.93$ & 25.89 & 52.13 & 30.65 & 13.69 & 2.13 & 1.41 & 17.16 \\
\cline { 2 - 9 } & $2.93-4.03$ & 4.75 & 16.66 & 24.76 & 43.17 & 6.54 & 8.88 & 13.49 \\
\cline { 2 - 9 } & $4.03-5.00$ & 4.68 & 20.50 & 27.38 & 37.30 & 6.63 & 8.19 & 11.73 \\
\cline { 2 - 9 } & $0.32-1.32$ & 49.05 & 43.44 & 26.97 & 27.48 & 0.99 & 1.12 & 13.53 \\
\cline { 2 - 9 } & $1.32-2.09$ & 27.61 & 61.89 & 21.68 & 12.70 & 2.14 & 1.60 & 13.49 \\
\cline { 2 - 9 } & $2.09-2.80$ & 14.37 & 47.65 & 36.15 & 10.98 & 2.93 & 2.29 & 15.48 \\
\cline { 2 - 9 } & $2.80-3.88$ & 3.62 & 21.90 & 27.57 & 33.06 & 8.58 & 8.89 & 13.49 \\
\cline { 2 - 8 } & $3.88-4.93$ & 5.45 & 18.23 & 25.59 & 42.05 & 5.70 & 8.43 & 11.99 \\
\hline
\end{tabular}

Source: own study.

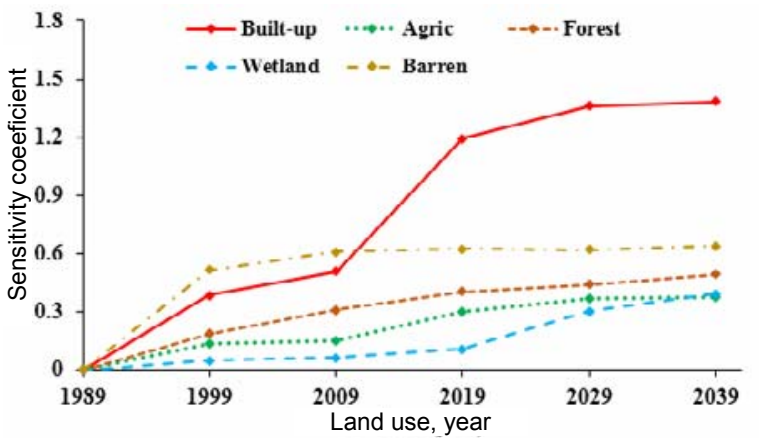

Fig. 8. Sensitivity of land use class to sediment yields (1989-2039); source: own study

fluence by climatic variables as demonstrated by NOTEBAERT et al. [2011].

\section{RAINFALL SCENARIOS AND SEDIMENT YIELD}

The two scenarios of high and low rainfall were simulated to observe the significance of rainfall to sediment yield due to urbanization. The result shows that the amount of sediment yield in a watershed was directly proportional to the amount or intensity of the rainfall. Our findings was similar to the result illustrated by OLD et al. [2003] and LÓPEZ-TARAZÓN et al. [2010], that the amount of sediment produced in a watershed increases during high storm events. Figure 9 shows the relationship between sediment yields in an increase urbanization under varying rainfall conditions. Although sediment yield was controlled by the amount of rainfall available, the result indicates that urbanization increases also influences it. An average of 12400 tons was reduced for $27 \%$ increase in the built-up land at high rainfall scenario. At low rainfall situation, 1490 tons was reduced at the same percentage increase. Comparison of the sensitivity of sediment yield to land-use change with rainfall variability without considering a land-use class contribution (Fig. 10) shows that both rainfall scenarios exhibit the same sensitivity, this implies that rainfall intensity only determined the amount of sediment yield from a watershed [ZHANG et al. 2016]. However, increase urbanization (or change in land-use) reduced sediment yield in proportion to the rainfall condition.

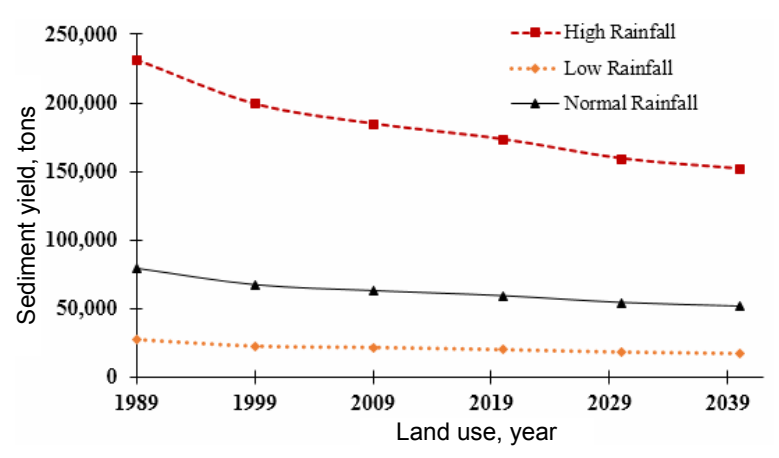

Fig. 9. Relationship between changes in sediment yield with varying rainfall events as land-use changes; source: own study

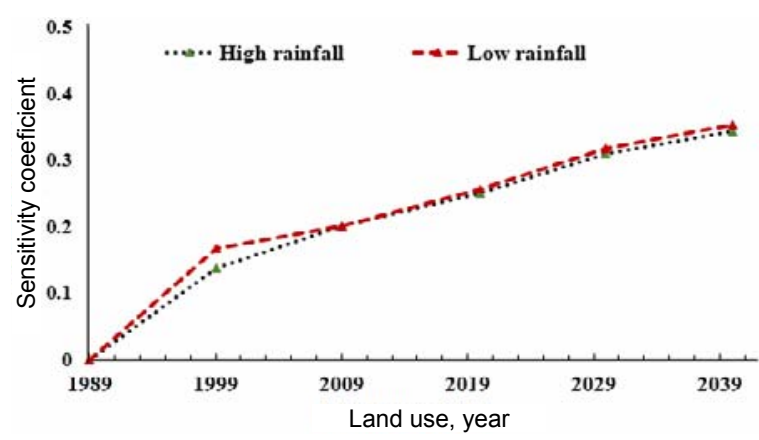

Fig. 10. Sensitivity of sediment yields to change in land-use at high and low rainfall scenarios in the watershed; source: own study 


\section{CONCLUSIONS}

The impact of urbanization on sediment yield at tropical coastal watershed was presented, using Skudai watershed as a case study. A historical urbanization trend was established using remote sensing. The land use dataset produced were used to predict potential future land use, constraint by urban development planned. The analysis of the temporal land use dataset shows that by 2039 , the watershed urban area will cover more than $49 \%$ of the watershed, while agricultural land will maintain at $27 \%$, and forest land $22 \%$.

The model calibration and validation result shows that it captured more than $50 \%$ of the variability of streamflow and sediment in the watershed. The model output was used to evaluate the impact of urbanization on sediment reduction considering normal, low and high rainfall conditions and the result provide the information that guides to the conclusions of this study. The result was analysed based on; (1) impact of urbanization on sediment yield reduction (2) sensitivity of the sediment yield on land use classes and, (3) impact of rainfall variability on sediment yield at the watershed scale. The results shows that sediment yield decreases with increase urban built-up and the sensitivity analysis indicates that sediment yield was more sensitive to a built-up area, forest land and bare land as urbanization progress. Agricultural land shows low sensitivity to sediment yield as compared to forest and barren land. It was observed that an increase of $27 \%$ of the built-up land will reduce 12400 tons of sediment yield at high rainfall and 1490 tons at low rainfall. The study reveals that increased urbanization reduced sediment yield in proportion to the rainfall condition.

This study has quantitatively established that increased urbanization will result to decrease in sediment yield at both watershed and sub-watershed scale. Also its shows the importance of planned urbanization in a watershed. It can be used as an effective tool for soil conservation and at the same time used for land utilization. Modelling approach provides information on the significance of temporal land-use in evaluating critical hydrological and water quality conditions of a watershed and sub-watershed, especially in coastal areas that were experiencing rapid development and human influx because sediment reduction from nonpoint sources will improve river water quality and that of the host estuary.

\section{Acknowledgement}

This research was supported by Malaysia Department of Irrigation and Drainage (DID), Department of Environment (DOE), and Indah Water Konsortium (IWK).

\section{REFERENCES}

Aqua Terra Consultants 2016. An enchanced expert system for calibration HSPF (HSPEXP+) [online]. [Access 15.11.2016]. Available at: http://www.aquaterra.com/ resources/downloads/HSPEXPplus.php
BAI S., WU-SENG L. 2005. Modeling sediment impact on the transport of fecal bacteria. Water Research. Vol. 39. Iss. 20 p. 5232-5240.

BARKDOll B.D., DuAn J.G. 2008. Sediment modeling: issues and Future directions. Journal of Hydraulic Engineering. Vol. 134. Iss. 3 p. 285.

Berghout A., Meddi M. 2016. Sediment transport modelling in wadi Chemora during flood flow events. Journal of Water and Land Development. No. 31 p. 23-31. DOI 10.1515/jwld-2016-0033.

BoraH D.K., KRUG E.C., Yoder D. 2008. Watershed sediment yield. In: Sedimentation engineering: processes, measurement, modeling, and practice. Ed. M. Garcia. MOP 110 ASCE p. 827-858.

BORAH D.K., XIA R., BERA M. 2001. Hydrologic and sediment transport modeling of agricultural watersheds. In: Proceedings of the World Water and Environmental Resources Congress. May 20-24 2001. Orlando FL. Washington CD. ASCE p. 1-10.

CANFIELD H.E., GOODRICH D.C., BuRNS I.S. 2005. Selection of parameters values to model post-fire runoff and sediment transport at the watershed scale in southwestern forests. In: Managing watersheds for human and natural impacts. Watershed Management Conference. July 1922, 2005. Williamsburg, VA, USA p. 1-12

De Vente J., Poesen J., Verstraeten G., Van Rompaey A., Govers G. 2008. Spatially distributed modelling of soil erosion and sediment yield at regional scales in Spain. Global and Planetary Change. Vol. 60. Iss. 3 p. 393-415.

DONIGIAN A.S., CRAWFORD N.H. 1976. Modeling nonpoint pollution from the land surface. Athens, GA. US Environmental Protection Agency, Office of Research and Development, Environmental Research Laboratory pp. 292.

Foody G.M. 2002. Status of land use classification accuracy assessment. Remote Sensing of Environment. Vol. 80. Iss. 1 p. 185-201.

FOX J.F., MARTIN D.K. 2014. Sediment fingerprinting for calibrating a soil erosion and sediment-yield model in mixed land-use watersheds. Journal of Hydrologic Engineering. Vol. 20. Iss. 6 C4014002.

Government of Malaysia 2009. DID Manual. Vol. 1. Flood management [online]. Kuala Lumpur. Department of Drainage and Irrigation. [Access 29.01.2016]. Available at: http://smanre.mygeoportal.gov.my/smanre/aduan/ Volume1_Flood\%20Management.pdf

GuZman C.D., Tilahun S.A., Dagnew D.C., Zegeye A.D., Tebebu T.Y., YitAFERU B., STEENHUIS T.S. 2017. Modeling sediment concentration and discharge variations in a small Ethiopian watershed with contributions from an unpaved road. Journal of Hydrology and Hydromechanics. Vol. 65. Iss. 1 p. 1-17.

Hayashi S., Murakami S., Watanabe M., Bao-Hua X. 2004. HSPF simulation of runoff and sediment loads in the upper Changjiang River basin, China. Journal of Environmental Engineering. Vol. 130. Iss. 7 p. 801815.

IRDA 2011. Integrated land use blue print for Iskandar Malaysia. Johor Bahru, Malaysia [online]. Iskandar Regional Development Authority. [Access 07.04.2016]. Available at: http://iskandarmalaysia.com.my/ blueprints/

JENSEN J.R. 2004. Digital change detection. In: Introductory digital image processing: A remote sensing perspective. Englewood Cliffs, NJ. Prentice-Hall p. 467-494. 
Kumar S., Mishra A., RAGHUwANSHI N.S. 2014. Identification of critical erosion watersheds for control management in data scarce condition using the SWAT model. Journal of Hydrologic Engineering. Vol. 20. Iss. 6 C4014008.

LÓPEZ-TARAZÓN J.A., BATAlla R.J., VERICAT D., BALASCH J.C. 2010. Rainfall, runoff and sediment transport relations in a mesoscale mountainous catchment: the River Isábena (Ebro basin). Catena. Vol. 82. Iss. 1 p. 23-34.

Mekonnen B.A., Mazurek K.A., Putz G. 2016. Sediment export modeling in cold-climate prairie watersheds. Journal of Hydrologic Engineering. Vol. 21. Iss. 5 05016005 .

Moriasi D.N., ARnold J.G., VAn Liew M.W., Bingner R.L., HARMEl R.D., VeITH T.L. 2007. Model evaluation guidelines for systematic quantification of accuracy in watershed simulations. Transactions of the ASABE. Vol. 50. Iss. 3 p. 885-900.

Mishra A., KAR S., Singh V.P. 2007. Determination of runoff and sediment yield from a small watershed in sub-humid subtropics using the HSPF model. Hydrological Processes. Vol. 21. Iss. 22 p. 3035-3045.

Notebaert B., Verstraeten G., Ward P., Renssen H., VAN ROMPAEY A. 2011. Modeling the sensitivity of sediment and water runoff dynamics to Holocene climate and land use changes at the catchment scale. Geomorphology. Vol. 126. Iss. 1 p. 18-31.

Old G.H., Leeks G.J., PACKMan J.C., SMith B.P., Lewis S., Hewitt E. J., Holmes M., Young A. 2003. The impact of a convectional summer rainfall event on river flow and fine sediment transport in a highly urbanised catchment: Bradford, West Yorkshire. Science of the Total Environment. Vol. 314 p. 495-512.

Pak J.H., Fleming M., Scharffenberg W., Gibson S., BRAUER T. 2015. Modeling surface soil erosion and sediment transport processes in the Upper North Bosque River Watershed, Texas. Journal of Hydrologic Engineering. Vol. 20. Iss. 1204015034.

Papanicolaou A. N., ABACi O. 2005. The development of an integrated watershed model for understanding the impacts of sediments on aquatic life. In: Managing watersheds for human and natural impacts. Watershed Management Conference. July 19-22, 2005. Williamsburg, VA, USA p. 1-7.

Russo J.P., Fox J.F., MARTIN D. 2009. Investigation of land-use change and hydrologic forcing upon streambank erosion and in-stream sediment processes using a watershed model and sediment tracers. In: World Environmental and Water Resources Congress: Great rivers. Reston, WA. ASCE p. 1-16

Russo S.A., HunN J., CHARACKLIS G.W. 2011. Considering bacteria-sediment associations in microbial fate and transport modeling. Journal of Environmental Engineering. Vol. 137. Iss. 8 p. 697-706.
Selmi K., Khanchoul K. 2016. Sediment load estimation in the Mellegue catchment, Algeria. Journal of Water and Land Development. No. 31 p. 129-137.

SHENK G.W., WU J., LiNKER L.C. 2012. Enhanced HSPF model structure for Chesapeake Bay watershed simulation. Journal of Environmental Engineering. Vol. 138. Iss. 9 p. 949-957.

SUDHIRA H.S., RAMACHANDRA T.V., JAGADISH K.S. 2004. Urban sprawl: Metrics, dynamics and modelling using GIS. International Journal of Applied Earth Observation and Geoinformation. Vol. 5. Iss. 1 p. 29-39.

Sun H., Forsythe W., WATERS N. 2007. Modeling urban land use change and urban sprawl: Calgary, Alberta, Canada. Networks and Spatial Economics. Vol. 7. Iss. 4 p. $353-376$.

USEPA 2006. EPA BASINS technical note 8: Sediment parameter and calibration guidance for HSPF [online]. Washington, DC. U.S. Environmental Protection Agency [Access 23.11.2015]. Available at: www.epa.gov/ waterscience/basins/docs/tecnote8.pdf

Weber C., Puissant A. 2003. Urbanization pressure and modeling of urban growth: example of the Tunis Metropolitan Area. Remote Sensing of Environment. Vol. 86. Iss. 3 p. 341-352.

Xian G., Crane M., Su J. 2007. An analysis of urban development and its environmental impact on the Tampa Bay watershed. Journal of Environmental Management. Vol. 85. Iss. 4 p. 965-976.

XiaO L., Yang X., Cai H. 2016. Responses of sediment yield to vegetation cover changes in the Poyang Lake drainage area, China. Water. Vol. 8. Iss. 4 p. 114.

ZEINIVAND H., SMEDT F.D. 2009. Spatially distributed modeling of soil erosion and sediment transport at watershed scale. In: World Environmental and Water Resources Congress: Great rivers. Reston, WA. ASCE p. 1-10.

Zhang S., Li Y., FAN W., YI Y. 2016. Impacts of rainfall, soil type, and land-use change on soil erosion in the Liusha River Watershed. Journal of Hydrologic Engineering. Vol. 22. Iss. 404016062.

ZhANG X., ZhANG X., Hu S., LIU T., Li G. 2013. Runoff and sediment modeling in a peri-urban artificial landscape: Case study of Olympic Forest Park in Beijing. Journal of Hydrology. Vol. 485 p. 126-138.

ZhaO G., KondOlf G.M., Mu X., Han M., He Z., Rubin Z., WANG F., GAO P., SUN W. 2017. Sediment yield reduction associated with land use changes and check dams in a catchment of the Loess Plateau, China. Catena. Vol. 148 p. $126-137$.

Zhou F., Xu Y., Chen Y., Xu C.Y., GaO Y., Du J. 2013. Hydrological response to urbanization at different spatio-temporal scales simulated by coupling of CLUE-S and the SWAT model in the Yangtze River Delta region. Journal of Hydrology. Vol. 485 p. 113-125. 


\section{Al-Amin D. BELLO, Noor B. HASHIM, Ridza M. HANIFFAH}

Wpływ urbanizacji na ładunek osadów w tropikalnych zlewniach analizowany na podstawie zmian użytkowania ziemi i w oparciu o model GIS

\section{STRESZCZENIE}

Duże opady atmosferyczne sprzyjają przemieszczaniu się osadów w skali zlewni w wyniku erozji gleby, powodując zamulanie koryta rzecznego. Procesy te można ograniczyć przez planową urbanizację. Urbanizację zlewni Skudai analizowano w perspektywie historycznej (przedziały 10-letnie) i w kontekście przyszłych zmian. Do modelowania przepływu osadu użyto programu symulacji hydrologicznej Fortran (HSPF), a wyniki modelowania wykorzystano do oceny zmniejszenia ilości osadu związanej z urbanizacją. Analiza wskazuje, że ładunek osadów maleje ze zwiększeniem udziału zabudowy miejskiej oraz z ograniczeniem powierzchni lasów i gruntów rolniczych. W warunkach intensywnych opadów ładunek osadu może zmaleć o $12400 \mathrm{t}$, gdy udział terenów zabudowanych zwiększy się o $27 \%$. W warunkach małych opadów ładunek zmniejszy się o 1490 t. Analiza wrażliwości klas użytkowania ziemi wykazała, że obszary zabudowane, lasy i ugory są bardziej wrażliwe na zmniejszenie ładunku osadu niż obszary podmokłe i grunty rolnicze, zarówno w warunkach dużego jak i małego natężenia opadów. Wyniki badań sugerują, że zwiększony udział terenów zabudowanych ogranicza ładunek osadów proporcjonalnie do ilości opadów, w związku z czym planowa urbanizacja może być wykorzystana jako alternatywne podejście do ochrony gleb w skali zlewni, niezależnie od warunków klimatycznych.

Słowa kluczowe: tadunek osadu, model HSPF, opad, tropikalna zlewnia, użytkowanie ziemi 